\title{
Expression pattern and polymorphism of three microsatellite markers in the porcine $C A 3$ gene
}

\author{
Jian $\mathrm{WU}^{1 * *}$, Donghai ZHoU ${ }^{2 * *}$, Changyan $\mathrm{DENG}^{3 *}$, Yuanzhu \\ XIONG ${ }^{3}$, Minggang LEI ${ }^{3}$, Fenge $\mathrm{LI}^{3}$, Siwen JiANG ${ }^{3}$, Bo ZUO ${ }^{3}$, Rong \\ ZHENG $^{3}$ \\ ${ }^{1}$ Department of Basic Veterinary Medicine, College of Veterinary Medicine, \\ Huazhong Agriculture University, Wuhan, 430070, P. R. China \\ ${ }^{2}$ Department of Clinical Veterinary Medicine, College of Veterinary Medicine, \\ Huazhong Agriculture University, Wuhan, 430070, P. R. China \\ ${ }^{3}$ Key Laboratory of Agricultural Animal Genetics, Breeding and Reproduction of Ministry \\ of Education and Key Laboratory of Swine Genetics and Breeding of Ministry of Agriculture, \\ Huazhong Agriculture University, Wuhan, 430070, P. R. China
}

(Received 12 February 2007; accepted 21 August 2007)

\begin{abstract}
Carbonic anhydrase III (CA3) is an abundant muscle protein characteristic of adult type-1, slow-twitch, muscle fibres. In order to further understand the functions of the porcine CA3 protein in muscle, the temporal and spatial distributions of its gene product were analysed and the association between the presence of specific polymorphisms and carcass traits in the pig was also examined. Real-time PCR revealed that the CA3 mRNA expression showed no differences with age in skeletal muscles from Yorkshire pigs at postnatal day-1, month-2, and month-4. We provide the first evidence that $C A 3$ is differentially expressed in the skeletal muscle of Yorkshire and Meishan pig breeds. In addition, the whole pig genomic DNA sequence of $C A 3$ was investigated and shown to contain seven exons and six introns. Comparative sequencing of the gene from three pig breeds revealed the existence of microsatellite $S J 160$ in intron 5 and microsatellite $S J 158$ and a novel microsatellite marker that includes a tandem repeat of (TC) in intron 4. We also determined the allele number and frequencies of the three loci in seven pig breeds and found that they are low polymorphic microsatellite markers. Statistical analysis showed that the $C A 3$ microsatellite polymorphism was associated with dressing percentage, internal fat rate, carcass length, rib number and backfat thickness in the pig.
\end{abstract}

pig / carbonic anhydrase III / expression pattern / microsatellite polymorphism

\footnotetext{
* Corresponding author: guanjian830@126.com

** These two authors contributed equally to this work. 


\section{INTRODUCTION}

Carbonic anhydrase III (CA3) is a member of a gene family encoding proteins, which catalyse the hydration of $\mathrm{CO}_{2}$ to generate protons and bicarbonate ions for cellular ion transport and $\mathrm{pH}$ homeostasis. It is an abundant muscle protein characteristic of adult type-1, slow-twitch, muscle fibres. The protein plays an important role in facilitated $\mathrm{CO}_{2}$ diffusion and diverse processes involving $\mathrm{H}^{+}$and $\mathrm{HCO}_{3}^{-}$transport [2]. Pig muscle carbonic anhydrase III is a $30 \mathrm{kDa}$ protein displaying three activities i.e. $\mathrm{CO}_{2}$ hydratase, acetate esterase and p-nitrophenyl phosphatase [10]. The $C A 3$ gene was first isolated in man [8]. Studies have shown that the expression of the $C A 3$ gene is strictly tissue-specific and is high in skeletal muscle and much lower in cardiac and smooth muscles [9]. The porcine $C A 3$ gene has been assigned to pig chromosome SSC4q11-q12 [4]. Previously, we have reported the cDNA sequence of the porcine $C A 3$ gene and polymorphic sites within this gene. Liu et al. [7] isolated the porcine $C A 3$ gene by mRNA differential display in the longissimus dorsi muscle tissues from a Landrace $\times$ Large White cross-combination. Wang et al. [11] analysed temporal and spatial expression differences of the $C A 3$ gene in the pig and reported that the CA3 protein is associated with intramuscular fat content and ham percentage.

In this study, we studied the allele frequencies of three microsatellite loci in the $C A 3$ gene in seven pig breeds. We report the allele frequencies and the results of association analyses of the three microsatellite markers within the $C A 3$ gene. Additionally, the expression patterns of the porcine $C A 3$ gene during the porcine skeletal muscle development and in different pig breeds were analysed.

\section{MATERIALS AND METHODS}

\subsection{Analysis of $C A 3$ expression levels}

Total RNA was extracted using TRIzoL reagent (Invitrogen, Carlsbad, CA, USA) from the longissimus dorsi of Yorkshire pigs at postnatal day-1, month2, and month-4 and Meishan pigs at postnatal month-2, respectively. Three animals were sampled for each breed and at each stage. Reverse transcriptase PCR was carried out using M-MLV Reverse Transcriptase (Promega, USA).

Amplification primer CA (Tab. I) was designed to analyse CA3 expression levels using porcine CA3 cDNA sequences (AY789514) as templates and Primer Express software. Quantitative PCR reactions were performed in $25 \mu \mathrm{L}$ volumes containing $12.5 \mu \mathrm{L} 2 \mathrm{~S}$ SBR Green Real-time PCR Master Mix 
Table I. Primers used in this study.

\begin{tabular}{|c|c|c|c|c|}
\hline $\begin{array}{c}\text { Primer } \\
\text { name }\end{array}$ & Sequence $\left(5^{\prime}\right.$ to $\left.3^{\prime}\right)$ & $\begin{array}{c}\text { Binding } \\
\text { region }\end{array}$ & $\begin{array}{c}\text { Annealing } \\
\text { temperature }\left({ }^{\circ} \mathrm{C}\right)\end{array}$ & Size (bp) \\
\hline $\mathrm{CA}$ & $\begin{array}{l}\text { F: GCCAAGGGAGACAACCAA } \\
\text { R: TGAGGAGCCCCAGTGAAG }\end{array}$ & $\begin{array}{l}\text { Exon } 2 \\
\text { Exon } 3\end{array}$ & 60 & 234 \\
\hline GAPDH-1 & $\begin{array}{l}\text { F: GAAGGTCGGAGTGAACGGAT } \\
\text { R: CTCATTTGATGTTGGCGGG }\end{array}$ & $\begin{array}{l}\text { Exon } 2 \\
\text { Exon } 4\end{array}$ & 60 & 251 \\
\hline CA-1 & $\begin{array}{l}\text { F: GTCCAGTGCCCACGAAGA } \\
\text { R: GGCAGAGCCAGGGTCATA }\end{array}$ & $\begin{array}{l}\text { Exon } 1 \\
\text { Exon } 2\end{array}$ & 58 & 918 \\
\hline CA2 & $\begin{array}{l}\text { F: CCTGAACAATGGGAAGAC } \\
\text { R: GAAGATGAAACTGGCGAA }\end{array}$ & $\begin{array}{l}\text { Exon } 2 \\
\text { Exon } 3\end{array}$ & 53 & 2502 \\
\hline CA-3 & $\begin{array}{l}\text { F: CACGGATCTGAGCACACT } \\
\text { R: ATGCCAACTACAGCCACT }\end{array}$ & $\begin{array}{l}\text { Exon } 3 \\
\text { Exon } 4\end{array}$ & 52 & 1855 \\
\hline CA-4 & $\begin{array}{l}\text { F: CCCTGATGGAGTGGCTGTA } \\
\text { R: TGGAACTCGCCTTTCTCAC }\end{array}$ & $\begin{array}{l}\text { Exon } 4 \\
\text { Exon } 5\end{array}$ & 57 & 1386 \\
\hline CA-5 & $\begin{array}{l}\text { F: ATAGGACGTGAGAAAGGCG } \\
\text { R: GTTGAAGTTCGTGAAGGGT }\end{array}$ & $\begin{array}{l}\text { Exon } 5 \\
\text { Exon } 6\end{array}$ & 57 & 1648 \\
\hline CA-6 & $\begin{array}{l}\text { F: CTGCGAGGAGTGCATTGTG } \\
\text { R: CTGCCCTTGATAGGCTGTG }\end{array}$ & $\begin{array}{l}\text { Exon } 6 \\
\text { Exon } 7\end{array}$ & 57 & 1130 \\
\hline SJ16 & $\begin{array}{l}\text { F: TGAAGTATTTGAGACAGAAGTTGAGG } \\
\text { R: TGAGCTACGACTGGAACTCCTAC }\end{array}$ & $\begin{array}{l}\text { Intron } 5 \\
\text { Intron } 5\end{array}$ & 55 & $179 / 205$ \\
\hline SJ15 & $\begin{array}{l}\text { F: TCAAGATATTTCTGCTAAGACAAG } \\
\text { R: CCTCGTGGATCAACTCTACTTC }\end{array}$ & $\begin{array}{l}\text { Intron } 4 \\
\text { Intron } 4\end{array}$ & 55 & $223 / 229 / 231$ \\
\hline TC & $\begin{array}{l}\text { F: TTGGTTTTCTTTTCCCTCTT } \\
\text { R: GCCTTTCTCACGTCCTATCT }\end{array}$ & $\begin{array}{l}\text { Intron } 4 \\
\text { Exon } 5\end{array}$ & 56 & $100 / 102 / 110$ \\
\hline
\end{tabular}

(TOYOBO, Japan), $1 \mu \mathrm{L}$ cDNA and $0.3 \mu \mathrm{M}$ of a terminal concentration of each primer. PCR was run on the Applied Biosystems 7500 Real-Time PCR System. Fluorescent signals were continually monitored at the end of each PCR cycle comprising $1 \mathrm{~min}$ at $95{ }^{\circ} \mathrm{C}$ for the initial denaturing step, $15 \mathrm{~s}$ at $95{ }^{\circ} \mathrm{C}, 15$ $\mathrm{s}$ at $60{ }^{\circ} \mathrm{C}$ and $50 \mathrm{~s}$ at $72{ }^{\circ} \mathrm{C}$ for a total of 40 cycles. The relative expression levels of the gene were analysed using the Comparative $\mathrm{Ct}$ method, in which glyceraldehyde-3-phosphate dehydrogenase $(G A P D H)$ was used as an internal control, to correct for the differences in the mRNA quantities. A specific primer pair (GAPDH-1, see Tab. I) that amplified a 251 bp fragment was designed and the PCR conditions were identical to those described above. A t-test was performed to conclude on the significance of the differences observed.

\subsection{Genomic DNA amplification and sequence analysis}

The cDNA sequence of the pig CA3 gene was compared with the human and mouse orthologous mRNA and their genomic sequence in order to 
predict the genomic organisation of the pig gene, which was confirmed by PCR amplification and sequencing. Six primer pairs were designed to amplify the genomic sequence including all introns (Tab. I). Three genomic DNA mixture pools from three pig breeds (six Yorkshire pigs, six landrace pigs and six Meishan pigs) were used. PCR was performed in a $25 \mu \mathrm{L}$ reaction mix containing the following: $200 \mathrm{ng}$ of genomic DNA pool, $200 \mu \mathrm{M}$ dNTP, $0.4 \mu \mathrm{mol}$ of each PCR primer, and 1U Taq DNA polymerase in the reaction buffer supplied by the manufacturer. PCR was run as follows: $94{ }^{\circ} \mathrm{C}$ for 4 min, 35 cycles of $94{ }^{\circ} \mathrm{C}$ for $50 \mathrm{~s}$, optimal temperature (Tab. I) for $50 \mathrm{~s}, 72{ }^{\circ} \mathrm{C}$ for $1 \mathrm{~min} 30 \mathrm{~s}$ and a final extension step at $72{ }^{\circ} \mathrm{C}$ for $10 \mathrm{~min}$. The purified PCR products were cloned into the pGEM-T vector (TaKaRa, Dalian, China) and were sequenced using standard M13 primers. DNA sequences were compiled using the DNA star software (Madison, WI, USA). The sequencing results of different pig breeds were compared using BLAST (http://www.ncbi.nlm.nih.gov).

\subsection{Detection of microsatellite polymorphisms}

Based on the BLAST results of the whole genomic sequence of the pig CA3 gene in Yorkshire, Landrace and Meishan breeds, microsatellite SJ160 was identified in intron 5, and microsatellite $S J 158$ and a novel microsatellite marker that includes a tandem repeat of $(\mathrm{TC})_{\mathrm{n}}$ were identified in intron 4. Primers SJ16 and SJ15, designed from the primer sequences of pig SJ160 (AB091132) and $S J 158$ (AB091130), were used to detect microsatellite $S J 160$ and $S J 158$ polymorphisms, respectively. Primer TC was designed from porcine CA3 DNA sequences and used to detect the polymorphism of the novel microsatellite $(\mathrm{TC})_{\mathrm{n}}(\mathrm{Tab} . \mathrm{I})$. PCR was performed in a $20 \mu \mathrm{L}$ reaction mix containing the following: $25 \mathrm{ng}$ of genomic DNA pool, $150 \mu \mathrm{M}$ dNTP, $0.25 \mu \mathrm{mol}$ of each PCR primer and $1 \mathrm{U}$ Taq DNA polymerase in the reaction buffer supplied by the manufacturer. PCR was run as follows: $94{ }^{\circ} \mathrm{C}$ for $4 \mathrm{~min}, 30$ cycles of $94{ }^{\circ} \mathrm{C}$ for $30 \mathrm{~s}, 5{ }^{\circ} \mathrm{C}$ for $30 \mathrm{~s}, 72{ }^{\circ} \mathrm{C}$ for $30 \mathrm{~s}$ and a final extension step at $72{ }^{\circ} \mathrm{C}$ for $10 \mathrm{~min}$. The denatured PCR products were analysed on $12 \%$ polyacrylamide denaturing sequencing gels, which were stained in a $\mathrm{AgNO}_{3}$ solution and then scanned by the Gel Imaging System (Olympia). To ensure the accuracy of the alleles analysed in our study, different samples of DNA alleles were cloned and sequenced.

\subsection{Statistical analysis}

Allele frequencies were studied in seven different pig populations. The microsatellite markers were genotyped in $330 \mathrm{~F} 2$ pigs of a Yorkshire $\times$ Meishan 


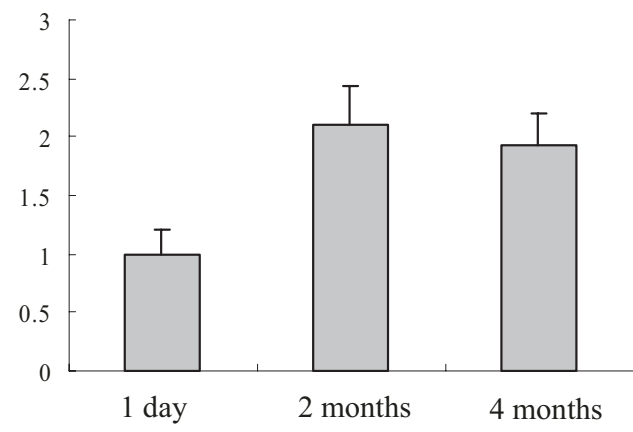

Figure 1. Temporal expression profiles of the porcine $C A 3$ gene. Relative levels of $C A 3$ mRNA were calculated using the Comparative $\mathrm{Ct}$ method with GAPDH as the reference gene in each sample. Bars represent the mean $\pm \mathrm{SE}(\mathrm{n}=3)$. Postnatal day-1, month-2 and month-4 indicate three stages of skeletal muscle development in Yorkshire pigs. The differences in the levels of expression were not significant $(\mathrm{P}>0.05)$ by t-test analysis.

reference family. The association studies between genotype and carcass traits were performed with the least squares method (GLM procedure, SAS ${ }^{\circledR}$ version 8.0). The model used to analyse the data was assumed to be:

$$
Y_{i j k}=\mu+G_{i}+S_{j}+F_{k}+b_{i j k} X_{i j k}+e_{i j k}
$$

where, $Y_{i j k}$ is the observation of the trait; $\mu$ is the least squares mean; $G_{i}$ is the effect of the ith genotype; $S_{j}$ is the effect of the $j^{\text {th }}$ sex $(j=1$ for male or 2 for female); $F_{k}$ is the effect of year; $b_{i j k}$ is the regression coefficient of the slaughter weight and $\mathrm{e}_{\mathrm{ijk}}$ is the random residual.

\section{RESULTS}

\subsection{Expression pattern of porcine $C A 3$ gene}

During the three stages of skeletal muscle development in Yorkshire pigs, we observed no statistically significant differences in CA3 mRNA expression (Fig. 1) as shown by t-test analysis $(\mathrm{P}>0.05)$. An expression pattern was also performed on the skeletal muscle of both Western Yorkshire and Chinese Meishan pigs at month-2. The porcine $C A 3$ gene was differentially expressed in the skeletal muscle of Yorkshire and Meishan breeds (Fig. 2) with a higher level in the skeletal muscle of Meishan than that of Yorkshire pigs. 


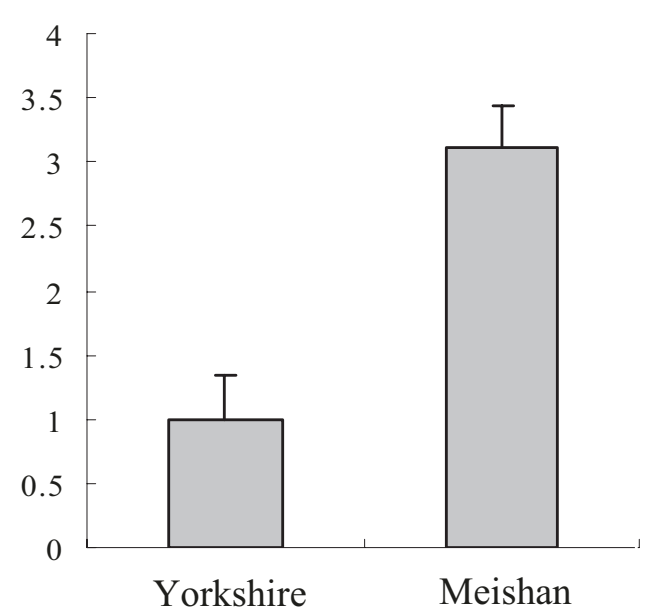

Figure 2. Differential expression analysis of the porcine $C A 3$ gene in different pig breeds. Real-time PCR analysis of the $C A 3$ gene in the skeletal muscle of Yorkshire and Meishan pigs at month-2. Relative levels of $C A 3$ mRNA were calculated using the Comparative $\mathrm{Ct}$ method with GAPDH as the reference gene in each sample. Bars represent the mean $\pm \mathrm{SE}(\mathrm{n}=3)$. The difference in the levels of expression was significant $(\mathrm{P}<0.05)$ by t-test analysis.

\subsection{Genomic sequence analysis of porcine $C A 3$ gene}

The resulting overlapping PCR products were assembled into a single contig revealing the pig $C A 3$ genomic sequence (Genbank accession number DQ675018). A 9589-bp genomic DNA sequence covering the entire coding region of porcine $C A 3$ was amplified using six gene-specific primer pairs (Tab. I) and compared with the cDNA sequence to clarify the exon/intron organisation. The porcine $C A 3$ gene is composed of seven exons and six introns. All splice donor and acceptor sites conform to the typical 5' GT-AG 3' rule. By comparing the sequence of these different pig breeds, we found that microsatellite $S J 160$ which includes a tandem repeat of $(\mathrm{CA})_{\mathrm{n}}$ is located approximately at $431 \mathrm{bp}$ from the beginning of intron 5. Microsatellite $S J 158$ which includes a tandem repeat of $(\mathrm{GT})_{\mathrm{n}}$ is located approximately at $240 \mathrm{bp}$ from the beginning of intron 4 and the novel microsatellite, which included a tandem repeat of $(\mathrm{TC})_{\mathrm{n}}$ is located approximately at 1264 bp from the beginning of intron 4 .

\subsection{Allele frequencies in different pig breeds}

We also studied the allele frequencies of the three microsatellite markers in seven pig breeds. For microsatellite marker $S J 160$, only two alleles were 
Table II. Allele frequencies at the CA3 SJ160 locus in seven pig breeds.

\begin{tabular}{lcccccc}
\hline \multirow{2}{*}{ Breed } & Number of & \multicolumn{3}{c}{ Genotype } & \multicolumn{2}{c}{ Allele frequencies (\%) } \\
\cline { 2 - 7 } & pigs & $A A$ & $A B$ & $B B$ & $A(\mathrm{CA})_{9}$ & $B(\mathrm{CA})_{22}$ \\
\hline Yorkshire & 42 & 42 & 0 & 0 & 100 & 0 \\
Landrace & 41 & 41 & 0 & 0 & 100 & 0 \\
Duroc & 26 & 26 & 0 & 0 & 100 & 0 \\
Meishan & 42 & 0 & 3 & 39 & 3.6 & 96.4 \\
Jianli & 20 & 3 & 9 & 8 & 37.5 & 62.5 \\
Qingping & 24 & 7 & 8 & 9 & 45.8 & 54.2 \\
Exi & 29 & 19 & 7 & 3 & 77.6 & 22.4 \\
\hline
\end{tabular}

Table III. Allele frequencies at the CA3 SJ158 locus in seven pig breeds.

\begin{tabular}{lccccccccccc}
\hline \multirow{2}{*}{ Breed } & Number of & \multicolumn{4}{c}{ Genotype } & \multicolumn{4}{c}{ Allele frequencies (\%) } \\
\cline { 2 - 11 } & pigs & $A A$ & $A B$ & $B B$ & $A C$ & $B C$ & $C C$ & $A(\mathrm{GT})_{18}$ & $B(\mathrm{GT})_{17}$ & $C(\mathrm{GT})_{14}$ \\
\hline Yorkshire & 34 & 1 & 15 & 18 & 0 & 0 & 0 & 25.0 & 75.0 & 0 \\
Landrace & 41 & 6 & 12 & 23 & 0 & 0 & 0 & 29.2 & 70.8 & 0 \\
Duroc & 21 & 0 & 2 & 15 & 0 & 4 & 0 & 4.8 & 85.7 & 9.5 \\
Wannan & 19 & 1 & 2 & 9 & 0 & 0 & 7 & 10.5 & 52.7 & 36.8 \\
Meishan & 39 & 0 & 0 & 0 & 0 & 0 & 39 & 0 & 0 & 100 \\
Jianli & 13 & 0 & 0 & 6 & 0 & 4 & 3 & 0 & 61.5 & 38.5 \\
Exi & 41 & 0 & 8 & 13 & 7 & 5 & 8 & 18.3 & 47.6 & 34.1 \\
\hline
\end{tabular}

detected with repeat numbers 9 and 22, for alleles $A$ and $B$, respectively. Frequencies of both alleles differ between the two pig breed types, while allele $A$ is fixed in three western commercial pig breeds, allele $B$ is prevalent in Chinese indigenous pig breeds, with the exception of Exi pigs (Tab. II). For microsatellite marker $S J 158$, three alleles were detected with repeat numbers 18, 17 and 14 , for alleles $A, B$ and $C$, respectively. Allele $B$ is prevalent in the two pig breed types, with the exception of Meishan pigs, in which allele $C$ is fixed (Tab. III). For the novel microsatellite marker that includes a tandem repeat of $(\mathrm{TC})_{\mathrm{n}}$, three alleles were also detected in six pig breeds with repeat numbers 17,13 and 12, for alleles $A, B$ and $C$, respectively. Allele $B$ is also prevalent in the two pig breed types, with the exception of Meishan pigs, in which allele $A$ is prevalent (Tab. IV).

\subsection{Association analysis of the three $C A 3$ microsatellite polymorphisms}

The results of the association analysis between the three $C A 3$ microsatellite polymorphisms and carcass traits in $330 \mathrm{~F}_{2}$ offspring (Yorkshire $\times$ Meishan) are given in Tables V, VI and VII. At the $S J 160$ locus, statistically significant 
Table IV. Allele frequencies of microsatellite marker $C A 3$, which includes a tandem repeat $(\mathrm{TC})_{\mathrm{n}}$ in six pig breeds.

\begin{tabular}{|c|c|c|c|c|c|c|c|c|c|c|}
\hline \multirow{2}{*}{ Breed } & \multirow{2}{*}{$\begin{array}{c}\text { Number of } \\
\text { pigs }\end{array}$} & \multicolumn{6}{|c|}{ Genotype } & \multicolumn{3}{|c|}{ Allele frequencies (\%) } \\
\hline & & $\overline{A A}$ & $\overline{A B}$ & $\overline{B B}$ & $A C$ & $\overline{B C}$ & $\overline{C C}$ & $A(\mathrm{TC})_{17}$ & $B(\mathrm{TC})_{13}$ & $C(\mathrm{TC})_{12}$ \\
\hline Yorkshire & 39 & 0 & 0 & 39 & 0 & 0 & 0 & 0 & 100 & 0 \\
\hline Duroc & 20 & 4 & 10 & 6 & 0 & 0 & 0 & 45 & 55 & 0 \\
\hline Landrace & 39 & 0 & 0 & 35 & 0 & 3 & 1 & 0 & 93.6 & 6.4 \\
\hline Wannan & 15 & 1 & 0 & 0 & 1 & 2 & 11 & 10 & 83.3 & 6.7 \\
\hline Meishan & 39 & 35 & 3 & 1 & 0 & 0 & 0 & 93.6 & 6.4 & 0 \\
\hline Jianli & 16 & 0 & 6 & 8 & 0 & 1 & 1 & 18.7 & 71.9 & 9.4 \\
\hline
\end{tabular}

Table V. Association analysis of the CA3 SJ160 polymorphism in 320 pigs. Least squares mean values with different letters are significantly different. Small letters: $\mathrm{P}<0.05$.

\begin{tabular}{ccrr}
\hline \multirow{2}{*}{ Traits } & \multicolumn{3}{c}{$C A 3$ genotype $(\mu \pm S E)$} \\
\cline { 2 - 4 } & \multicolumn{1}{c}{$A A(120)$} & \multicolumn{1}{c}{$B B(155)$} & \multicolumn{1}{c}{$B(45)$} \\
\hline Carcass length $(\mathrm{cm})$ & $91.122 \pm 0.371^{\mathrm{ab}}$ & $90.445 \pm 0.326^{\mathrm{a}}$ & $92.162 \pm 0.605^{\mathrm{b}}$ \\
Backfat thickness & $3.671 \pm 0.069^{\mathrm{ab}}$ & $3.781 \pm 0.061^{\mathrm{a}}$ & $3.503 \pm 0.112^{\mathrm{b}}$ \\
at shoulder $(\mathrm{cm})$ & & & \\
Backfat thickness & $2.118 \pm 0.064^{\mathrm{a}}$ & $2.017 \pm 0.056^{\mathrm{ab}}$ & $1.839 \pm 0.104^{\mathrm{b}}$ \\
at buttock $(\mathrm{cm})$ & & & \\
\hline
\end{tabular}

associations with carcass length, backfat thickness at the shoulder and backfat thickness at the buttock were found, but no significant conclusion could be drawn on other carcass traits. Pigs with the $B B$ genotype had significantly higher carcass length and lower backfat thickness when compared with pigs with the $A A$ or $A B$ genotypes (Tab. V).

At the $S J 158$ locus, statistically significant associations with fat percentage, lean meat percentage, dressing percentage, internal fat rate, rib number, backfat thickness at the $6-7^{\text {th }}$ thorax and backfat thickness at the buttock were found, but no significant conclusion could be drawn on other carcass traits. Pigs with the $A A$ genotype had the highest lean meat percentage and rib number, and the lowest fat percentage and dressing percentage, while pigs with the $B C$ genotype had the highest fat percentage, internal fat rate and backfat thickness in comparison with pigs with other genotypes. Allele $A$ present in Yorkshire pigs is associated with increased lean meat percentage and rib number, and decreased fat percentage (Tab. IV).

At the novel microsatellite (TC) locus, statistically significant associations with dressing percentage, internal fat rate, carcass length, backfat thickness at the buttock and average backfat thickness were found, but no significant 
Table VI. Association analysis of the CA3 SJ158 polymorphism in 320 pigs. Least squares mean values with different letters are significantly different. Small letters: $\mathrm{P}<0.05$, capital letters: $\mathrm{P}<0.01$.

\begin{tabular}{|c|c|c|c|c|c|c|}
\hline \multirow{2}{*}{ Traits } & \multicolumn{6}{|c|}{$C A 3$ genotype $(\mu \pm S E)$} \\
\hline & $A A(36)$ & $A B(47)$ & $A C(90)$ & $B B(21)$ & $B C(45)$ & $C C(81)$ \\
\hline $\begin{array}{c}\text { Fat percentage } \\
(\%)\end{array}$ & $22.601 \pm 0.787^{\mathrm{a}}$ & $24.549 \pm 0.685^{\mathrm{ab}}$ & $23.084 \pm 0.497^{\mathrm{a}}$ & $22.891 \pm 1.053^{\mathrm{ab}}$ & $24.948 \pm 0.711^{\mathrm{b}}$ & $23.547 \pm 0.518^{\mathrm{ab}}$ \\
\hline $\begin{array}{c}\text { Lean meat } \\
\text { percentage }(\%)\end{array}$ & $59.063 \pm 1.079^{\mathrm{a}}$ & $55.813 \pm 0.956^{\mathrm{b}}$ & $56.887 \pm 0.645^{\mathrm{ab}}$ & $56.541 \pm 2.428^{\mathrm{ab}}$ & $55.979 \pm 0.757^{\mathrm{b}}$ & $55.776 \pm 0.749^{b}$ \\
\hline $\begin{array}{c}\text { Dressing } \\
\text { percentage }(\%)\end{array}$ & $71.591 \pm 0.74^{\mathrm{a}}$ & $73.125 \pm 0.664^{\mathrm{ab}}$ & $72.024 \pm 0.477^{\mathrm{a}}$ & $74.282 \pm 0.974^{\mathrm{b}}$ & $73.882 \pm 0.717^{b}$ & $73.862 \pm 0.496^{\mathrm{b}}$ \\
\hline $\begin{array}{c}\text { Internal fat rate } \\
\qquad \%)\end{array}$ & $3.101 \pm 0.104^{\mathrm{A}}$ & $3.103 \pm 0.106^{\mathrm{A}}$ & $3.099 \pm 0.098^{\mathrm{A}}$ & $3.105 \pm 0.110^{\mathrm{A}}$ & $3.497 \pm 0.100^{\mathrm{B}}$ & $3.035 \pm 0.099^{\mathrm{A}}$ \\
\hline Rib number & $14.913 \pm 0.106^{\mathrm{Aa}}$ & $14.458 \pm 0.092^{\mathrm{B}}$ & $14.757 \pm 0.067^{\mathrm{A}}$ & $14.500 \pm 0.142^{b}$ & $14.629 \pm 0.096^{\mathrm{b}}$ & $14.773 \pm 0.070^{\mathrm{A}}$ \\
\hline $\begin{array}{l}\text { Backfat thickness } \\
\text { at } 6-7^{\text {th }} \text { thorax }(\mathrm{cm})\end{array}$ & $2.844 \pm 0.104^{\mathrm{ab}}$ & $2.776 \pm 0.090^{\mathrm{a}}$ & $2.782 \pm 0.065^{\mathrm{a}}$ & $2.843 \pm 0.139^{\mathrm{ab}}$ & $3.039 \pm 0.094^{b}$ & $2.851 \pm 0.068^{\mathrm{ab}}$ \\
\hline $\begin{array}{l}\text { Backfat thickness } \\
\text { at buttock }(\mathrm{cm})\end{array}$ & $1.913 \pm 0.118^{\mathrm{A}}$ & $2.021 \pm 0.103^{\mathrm{a}}$ & $1.913 \pm 0.075^{\mathrm{A}}$ & $1.860 \pm 0.158^{\mathrm{a}}$ & $2.336 \pm 0.107^{\mathrm{Bb}}$ & $1.976 \pm 0.078^{\mathrm{A}}$ \\
\hline
\end{tabular}


Table VII. Association analysis of the $C A 3$ (TC) nolymorphism in 326 pigs. Least squares mean values with different letters are significantly different. Small letters: $\mathrm{P}<0.05$, capital letters: $\mathrm{P}<0.01$.

\begin{tabular}{cccc}
\hline \multirow{2}{*}{ Traits } & \multicolumn{3}{c}{$C A 3$ genotype $(\mu \pm S E)$} \\
\cline { 2 - 4 } & $A A(51)$ & $A B(159)$ & $B B(116)$ \\
\hline Dressing percentage (\%) & $74.084 \pm 0.632^{\mathrm{a}}$ & $73.029 \pm 0.355^{\mathrm{ab}}$ & $72.575 \pm 0.416^{\mathrm{b}}$ \\
Internal fat rate (\%) & $2.954 \pm 0.097^{\mathrm{a}}$ & $3.198 \pm 0.055^{\mathrm{b}}$ & $3.178 \pm 0.064^{\mathrm{ab}}$ \\
Carcass length (cm) & $92.558 \pm 0.573^{\mathrm{Aa}}$ & $90.644 \pm 0.324^{\mathrm{Bb}}$ & $91.143 \pm 0.380^{\mathrm{ABb}}$ \\
Backfat thickness at & $1.852 \pm 0.098^{\mathrm{a}}$ & $2.104 \pm 0.056^{\mathrm{ab}}$ & $2.078 \pm 0.065^{\mathrm{b}}$ \\
buttock (cm) & & & \\
Average backfat & $1.931 \pm 0.319^{\mathrm{a}}$ & $2.968 \pm 0.197^{\mathrm{b}}$ & $2.688 \pm 0.177^{\mathrm{ab}}$ \\
thickness (cm) & & & \\
\hline
\end{tabular}

conclusion could be drawn on other carcass traits. Pigs with the $A A$ genotype had significantly higher dressing percentage and carcass length but lower internal fat rate and backfat thickness when compared to pigs with $B B$ or $A B$ genotypes (Tab. VII).

\section{DISCUSSION}

The real-time PCR technique is an accurate and sensitive method that has been widely used to determine the relative quantification of mRNA or DNA. In our current study, we employed this technique to assess the changes in the expression of CA3 mRNA during three important stages of skeletal muscle development in pig and different pig breeds. This provides some information on the functions of $C A 3$ during muscle development. Liu et al. [7] first discovered that the porcine $C A 3$ gene was differentially expressed in the skeletal muscle from a Landrace $\times$ Large White cross-combination. In our study, the porcine $C A 3$ gene was also differentially expressed in the skeletal muscle of Yorkshire and Meishan pig breeds. The results of expression profiles showed that the expression levels of $C A 3$ increased in skeletal muscles from prenatal 33- to 65-day-old Chinese Tongcheng pigs and subsequently decreased to a steady state in prenatal 90-day-old, postnatal 2-day-old, postnatal 28-dayold, and pregnant 65-day-old pigs [11]. Therefore, our results are supported by these former reports. We also observed that the CA3 mRNA expression does not change in the skeletal muscle from postnatal day 1 to 4-month-old Yorkshire pigs.

In our study, we isolated the whole genomic DNA sequence of the porcine CA3 gene and found that its structural features were identical to those 
reported by Wang et al. [11]. Moreover, we analysed the polymorphism of microsatellites present in the whole genomic DNA sequence of $C A 3$. Previously, microsatellite markers SJ160, SJ158 and SJ159 (associated with the $C A 3$ gene) were located at the position $46.9 \mathrm{cM}$ on the SSC4 linkage map [3]. In our study on the pig $C A 3$ gene representing about $10 \mathrm{~kb}$, we identified only microsatellites SJ160, SJ158 and a novel microsatellite locus within introns but not the SJ159 locus. The presence of SSRs within introns has been documented in a number of species and they are mainly composed of monomers affecting gene transcription, mRNA correct splicing or export to the cytoplasm [6]. In animal breeding studies, microsatellite markers play an important role in constructing genetic maps, QTL mapping and in analysing the function of structural genes. We speculate that these microsatellites represent important markers both for fine QTL mapping of production traits and for the study of the expression of porcine $C A 3$.

An assessment of the relationships between the $C A 3$ functions and the characterisation of its genomic sequence, with its many polymorphisms and repeat elements, was also undertaken. Three microsatellite polymorphic sites were used to further analyse their relationships with important pig economic traits. Moreover, differences between the Chinese and western breeds were revealed by allele frequency analyses of the three microsatellite polymorphisms. Our findings show that the three polymorphic sites, SJ160, SJ158 and the novel microsatellite (TC $)_{\mathrm{n}}$, can be significantly associated with the following carcass traits i.e. carcass length, backfat thickness, dressing percentage, internal fat rate, lean meat percentage, etc. We observed a greater carcass quality in individuals with the $B B$ genotype at the $S J 160$ locus and with the $A A$ genotype at the $(\mathrm{TC})_{\mathrm{n}}$ locus. However, since these genotypes are the most frequent in the Meishan breed, the observation of this gene effect is not consistent with known phenotype differences in this breed. It is possible that Meishan pigs have the favourable recessive allele at the two loci. However, the number of individuals analysed for allele frequencies and association is limited and the genetic background of the Yorkshire $\times$ Meishan reference family might influence the observed results and result in a discrepancy. In a previous study [12], we identified another polymorphic site in the $C A 3$ gene, which is significantly associated with meat production traits i.e. backfat thickness, dressing percentage and lean meat percentage. Moreover, the porcine $C A 3$ gene has been assigned to pig chromosome 4 (SSC4) at position $46.9 \mathrm{cM}[3,4]$. SSC4 encompasses several quantitative trait loci that are economically important in pig breeding. QTL for various carcass traits have been detected in the interval between $V$-ATPase and NGFB of chromosome $4[1,5]$. In the same F2 individuals 
(Yorkshire $\times$ Meishan), a QTL affecting backfat thickness was found at position $53 \mathrm{cM}$, between markers SW835 and SW752 [13]. Therefore, based on previous findings and our present results, the pig $C A 3$ gene is located close to QTL affecting carcass traits and may be responsible for these QTL. It is also possible that the $C A 3$ gene may be a candidate gene for fat traits of carcass that regulate skeletal muscle development and consequently affect commercial production traits in the pig.

\section{ACKNOWLEDGEMENTS}

We would like to thank teachers and graduate students at the Key Laboratory of Swine Genetics and Breeding, Ministry of Agriculture for managing and slaughtering research flocks. This study was supported financially by the National High Technology Research and Development program of China ('863' project) (2003AA243030 and 2006AA10Z1D6).

\section{REFERENCES}

[1] Cepica S., Stratil A., Kopecny M., Blazkova P., Schroffel J.J.R., Davoli R., Fontanesi L., Reiner G., Bartenschlager H., Moser G., Geldermann H., Linkage and QTL mapping for Sus scrofa chromosome 4, J. Anim. Breed. Genet. 120 (2003) 28-37.

[2] Edwards Y.H., Tweedie S., Lowe N., Lyons G., Carbonic anhydrase 3 (CA3), a mesodermal marker, Symp. Soc. Exp. Biol. 46 (1992) 273-283.

[3] Fujishima-Kanaya N., Toki D., Suzuki K., Sawazaki T., Hiraiwa H., Iida M., Hayashi T., Uenishi H., Wada Y., Ito Y., Awata T., Development of 50 geneassociated microsatellite markers using BAC clones and the construction of a linkage map of swine chromosome 4, Anim. Genet. 34 (2003) 135-141.

[4] Fujishima-Kanaya N., Ito Y., Suzuki K., Sawazaki T., Hiraiwa H., Uenishi H., Awata T., The porcine homologues of six genes located on human chromosome 8 (RAB2, CA3, PTDSS1, MATN2, FZD6 and SQLE) assigned to porcine chromosome 4 by fluorescence in situ hybridization, Anim. Genet. 35 (2004) 501-502.

[5] Geldermann H., Muller E., Moser G., Reiner G., Bartenschlager H., Cepica S., Stratil A., Kuryl J., Moran C., Davoli R., Brunsch C., Genome wide linkage and QTL mapping in porcine F2 families generated from Pietrain, Meishan and Wild Boar crosses, J. Anim. Breed. Genet. 120 (2003) 363-393.

[6] Li Y.C., Korol A.B., Fahima T., Nevo E., Microsatellites within genes: Structure function, and evolution, Mol. Biol. Evol. 21 (2004) 991-1007.

[7] Liu Y., Xiong Y., Deng C., Isolation, sequence analysis and expression profile of a novel swine gene differentially expressed in the longissimus dorsi muscle tissues from Landrace Large White cross-combination, Acta Biochem. Biophys. Sinica 37 (2005) 186-191. 
[8] Lloyd J.C., Isenberg H., Hopkinson D.A., Edwards Y.H., Isolation of a cDNA clone for the human muscle specific carbonic anhydrase III, Ann. Hum. Genet. 49 (1985) 241-251.

[9] Lloyd J.C., McMillan S., Hopkinson D.A., Edwards Y.H., Nucleotide sequence and derived amino acid sequence of a cDNA encoding human muscle carbonic anhydrase, Gene 41 (1986) 233-239.

[10] Pullan L.M., Noltmann E.A., Purification and properties of pig muscle carbonic anhydrase III, Biochim. Biophys. Acta 839 (1985) 147-154.

[11] Wang H.L., Zhu Z.M., Wang H., Yang S.L., Zhao S.H., Li K., Molecular characterization and association analysis of porcine $C A 3$, Cytogenet. Genome Res. 115 (2006) 129-133.

[12] Wu J., Deng C.Y., Xiong Y.Z., Zhou D.H., Lei M.G., Zuo B., Li F.E., Wang J., cDNA cloning and polymorphism of the porcine carbonic anhydrase III (CA3) gene, Asian-Aust. J. Anim. Sci. 19 (2006) 324-328.

[13] Zuo B., Xiong Y., Su Y., Deng C., Zheng R., Lei M., Yu L., Mapping and genetic effect analysis of swine Quantitative Trait Loci using 24 microsatellites, Acta Vet. Zootech. Sinica 34 (2003) 139-146. 